\title{
Transfection of Mammalian Cells with Fluorescent Protein Fusions
}

\author{
David L. Spector and Robert D. Goldman
}

\section{INTRODUCTION}

Fluorescent protein fusions (FPFs) have been used to address a wide range of questions in individual cells as well as in specific tissues of particular organisms. However, investigators must take extreme care when using FPFs to ensure that the resultant fusion protein is expressed at or close to the endogenous level of the parent protein, and also that it is full length, localizes correctly, and behaves normally once incorporated in the cell. Although transient transfection methods can be used to introduce DNA coding for FPFs, in many cases it is beneficial and/or essential to develop stable cell lines expressing the fusion protein of interest. In addition to providing more native levels of expression, the individual clones can be generated from single cells, the integration site of the plasmid can be mapped, and the copy number can be determined. Moreover, because every cell in the population is expressing the fusion protein, cell cycle analyses and biochemical fractionation are significantly easier to accomplish. This article presents a protocol for generating, selecting, and screening stable cell lines expressing FPFs.

\section{RELATED INFORMATION}

More information on FPFs can be found in Constructing and Expressing Fluorescent Protein Fusions (Spector and Goldman 2010). The last section of this Spector and Goldman (2010) article, in particular Development of Stable Mammalian Cell Lines Expressing Fluorescent Protein Fusions, should be reviewed prior to beginning this protocol. Information is also available on Fluorescent Protein Tracking and Detection: Fluorescent Protein Structure and Color Variants (Rizzo et al. 2009) and Biarsenical Labeling of Tetracysteine-Tagged Proteins for Tracking Existing and Newly Synthesized Pools of Proteins (Pattnaik and Panda 2009).

For more information on procedures and optimization of transfection by electroporation, see DNA Transfection by Electroporation (Sambrook and Russell 2006a), Electroporation (Nagy et al. 2006), Optimizing Electrotransfection of Mammalian Cells In Vitro (Li 2006), and Transfection by Electroporation of RAW 264.7 Macrophages (Smale 2010a). Other methods for transfecting cells with DNA are described in Transfection Mediated by DEAE-Dextran: High-Efficiency Method (Sambrook and Russell 2006b), Calcium-Phosphate-Mediated Transfection of Eukaryotic Cells with Plasmid DNAs (Sambrook and Russell 2006c), Calcium-Phosphate-Mediated Transfection of Cells with High-Molecular-Weight Genomic DNA (Sambrook and Russell 2006d), Calcium Phosphate Transfection of 3T3 Fibroblasts (Smale 2010b), and DEAE-Dextran Transfection of Lymphocyte Cell Lines (Smale 2010c).

\section{MATERIALS}

CAUTIONS AND RECIPES: Please see Appendices for appropriate handling of materials marked with $<!>$, and recipes for reagents marked with $<R>$.

Adapted from Live Cell Imaging, 2nd edition (ed. Goldman et al.).

CHSL Press, Cold Spring Harbor, NY, USA, 2010.

Cite as: Cold Spring Harb Protoc; 2010; doi:10.1101/pdb.prot5517

www.cshprotocols.org 


\section{Reagents}

Antibiotic (appropriate to selection method used)

Cells to be transfected

Culture medium

$<$ R $>$ Phosphate-buffered saline (PBS) (sterile)

Sample for preparing DNA for transfection (e.g., prepare using kit from QIAGEN; see Step 1)

Sheared salmon sperm DNA (AMRESCO)

$<$ ! Trypsin

\section{Equipment}

Centrifuge

Cloning rings (optional; see Step 12)

Conical tube $(15-\mathrm{mL})$

Coverslips (small, round) (for screening by fluorescence microscopy; see Step 13.i)

Electroporation cuvette (4-mm gap; model 640; BTX)

Electroporator (e.g., Gene Pulser II [Bio-Rad] or equivalent)

Fluorescence microscope (Carl Zeiss)

Incubator preset to $37^{\circ} \mathrm{C}$

Marker (permanent)

Micropipettor and tips (e.g., Gilson Pipetman P1000 or P200 for Step 12)

Petri dishes (100-mm)

Pipettes

Plates (6-well and 24-well)

\section{METHOD}

\section{DNA Preparation and Transfection (Day 1)}

1. Prepare DNA according to the manufacturer's instructions for the transfection procedure.

For electroporation of HeLa cells, this protocol has been successful with a mixture of $2 \mu \mathrm{g}$ of target DNA and 20-40 $\mathrm{mg}$ of sheared salmon sperm DNA added directly to the cuvette.

2. Transfect the cells:

\section{For transfections that require attached cells}

i. Prepare DNA according to the specific transfection protocol and add it directly to the cells. Incubate the cells for $24 \mathrm{~h}$.

\section{For electroporation}

ii. Trypsinize the cells for the minimum time necessary for removal from culture dishes.

iii. Suspend and gently centrifuge the cells in a $15-\mathrm{mL}$ conical tube to obtain a cell pellet. Each plate of $80 \%$ confluent cells can be used for four separate transfections.

iv. Resuspend the pellet in $800 \mu \mathrm{L}$ (for example) of culture medium.

v. Add $200 \mu \mathrm{L}$ of cell suspension to each electroporation cuvette containing DNA. Mix the cells and DNA.

Adjust settings on the electroporator ( $240 \mathrm{~V} ; 950 \mu \mathrm{F}$ for HeLa cells) and electroporate.

3. Allow the cells to sit for $2 \mathrm{~min}$ at room temperature following electroporation. Add $1 \mathrm{~mL}$ of culture medium to the cuvette and mix well to break apart clusters of dead cells.

4. Plate the cells directly into a $100-\mathrm{mm}$ Petri dish with $10 \mathrm{~mL}$ of culture medium. Incubate the cells for $24 \mathrm{~h}$ at $37^{\circ} \mathrm{C}$. 


\section{Washing the Transfected Cells (Day 2)}

5. Remove the culture medium from the transfected cells. Wash the cells three times with sterile PBS and add fresh medium. Incubate the cells for $24 \mathrm{~h}$ at $37^{\circ} \mathrm{C}$.

For very fast-growing cells such as baby hamster kidney (BHK) cells, each step of this procedure can be performed ahead of schedule to prevent the cells from becoming too confluent.

\section{Trypsinizing and Splitting the Cells (Day 3)}

6. Trypsinize the cells long enough to obtain a single-cell suspension.

7. Prepare a total of $10100-\mathrm{mm}$ Petri dishes, each containing $8 \mathrm{~mL}$ of medium. Reuse the original dish, because some transfected cells will be left behind.

8. Resuspend the pellet of transfected cells in $10 \mathrm{~mL}$ of medium. Plate $1 \mathrm{~mL}$ per dish. Incubate the cells for $24 \mathrm{~h}$ at $37^{\circ} \mathrm{C}$.

\section{Antibiotic Selection (Beginning at Day 4)}

9. Perform antibiotic selection:

i. Prepare $10 \mathrm{~mL}$ of a $10 \mathrm{X}$ stock (in medium) of the appropriate antibiotic used for selection.

ii. Add $1 \mathrm{~mL}$ of $10 \mathrm{X}$ antibiotic near the edge of each dish, swirling to mix well.

iii. Monitor the progress of the transfection every few days by observing the amount of cell death and the color of the culture medium.

Yellow medium will be due to cell overgrowth.

iv. If the medium becomes very dense with cell debris, change to fresh antibiotic medium after 4-7 d.

Colony Transfer and Selection ( Days 14-21)

Colonies of stably transfected cells should have appeared during this time.

10. View the colonies by carefully holding the plate up to the ceiling lights.

11. Allow the colonies to reach a diameter of $\sim 4 \mathrm{~mm}$. Mark the position of each colony with a permanent marker on the bottom of the dish. Choose $\sim 10$ colonies per plate for screening, trying to choose only colonies that are not in contact with other colonies.

The more clones screened, the better the chance of obtaining a positive clone or several clones with different levels of fusion protein expression.

12. Transfer the selected colonies to 24 -well plates by scraping the colonies with the tip of a pipette (using either a Gilson Pipetman P1000 or P200) while simultaneously releasing the plunger to draw up the cells with medium.

An alternative is to use cloning rings to trypsinize each colony, but this technique is much more difficult to use. These 24-well plates are the stock plates. Handle them with great care and keep them sterile.

Screening ( Days 21-28)

13. Screen individual wells in the 24-well plates as the cells become confluent: In the case of scraped colonies, confluence would be defined as multiple large clumps of cells (4-6 mm in diameter) in several places in the well, rather than a monolayer covering the entire bottom of the well.

i. Prepare a second set of 24-well plates to use for screening. If screening by fluorescence microscopy, place a small round coverslip in each well.

ii. Mark the top of each well with its corresponding clone number.

iii. Rinse confluent cells with sterile PBS and add three to four drops of trypsin (place in the incubator to loosen large clumps). Add $1 \mathrm{~mL}$ of culture medium with serum when the cells are released and pipette gently to resuspend the cells. 
iv. Transfer $\sim 25 \%-50 \%$ of the cells to the screening wells.

About $25 \%$ of the remaining stock cells can be discarded, if desired, to avoid overgrowing the stock plates. The recommended goal is to screen the clones transferred to the screening plates before the wells in the stock plates reach confluence again.

\section{Expanding Stable Clones}

14. After stable clones are identified, transfer them to 6-well dishes and then to $100-\mathrm{mm}$ dishes. From this point, the clones can be expanded to make frozen stocks.

If a clone contains a mixture of positive and negative cells, simple serial dilution procedures or fluorescenceactivated cell sorting can be used to isolate the positive cells. Clones can then be derived from individual positive cells.

\section{DISCUSSION}

\section{Is the Fusion Protein Localized Correctly?}

Irrespective of whether the fusion protein is expressed transiently or stably, it must be determined whether it is localized correctly. If familiar with the localization of the protein under study, examine its localization using a fluorescence microscope equipped with the correct excitation/emission filter cube for the respective fluorescent protein (see Fluorescent Protein Tracking and Detection: Fluorescent Protein Structure and Color Variants [Rizzo et al. 2009]). If the protein under study has not previously been localized, perform a side-by-side localization with an antibody that specifically recognizes the protein under study. This is easily accomplished by fixing the cells and processing for single indirect immunofluorescence. For example, in the case of cells transfected with enhanced green fluorescent protein (GFP)-tagged constructs, the secondary antibody could be tagged with Texas Red. Using high-resolution confocal microscopy, complete colocalization of the two fluorophores should be achieved. If an antibody is not available, double-label localization should be performed with an antibody to a partner protein that is expected to be colocalized with the protein of interest. Evaluate any suspicious or novel localization very carefully because the FP tag can, in certain cases, interfere with the correct localization of the protein under study. In addition, the tag can alter protein folding and/or result in aggregation, most notably in the cytoplasm. Such aberrant localization, for example, with an amino-terminal fusion protein, may not be observed with a carboxy-terminal fusion protein or vice versa. Suspicious localization of the fusion protein should be taken very seriously, and further studies should be placed on hold until the localization is understood. Of course, for a novel protein of unknown function, it may not be easy to distinguish between correct and aberrant localization of the fusion protein. In these cases, every attempt should be made to prepare an antibody to determine the normal localization of the endogenous protein in nontransfected cells.

\section{Is the Fusion Protein Functional?}

As is the case with any fusion protein, and in particular those containing the 27-kDa fluorescent protein, one must determine whether the fusion protein is functional. However, in many cases, the term "functional" is rather loosely defined. Upon development of an FPF, the first parameters that should be investigated are (1) the protein's localization as discussed above, (2) whether the fusion protein is full length, and (3) its expression level as compared with the endogenous protein. The last two parameters can be determined simultaneously by immunoblot analysis using an antibody to the endogenous protein that will recognize both the endogenous protein and the FPF. In this case, there will be a retardation of mobility in SDS-PAGE (sodium dodecyl sufate-polyacrylamide gel electrophoresis) preparations as a result of the increased molecular weight of the fusion protein. If such an antibody is not available, antibodies to GFP (e.g., a monoclonal antibody available from Roche Applied Science) can be used to determine the size of the expressed fusion protein. This characterization is extremely important, because expression of a truncated protein can result in incorrect interpretation, and if followed up, can result in a significant loss of time and resources. Immunoprecipitation followed by immunoblotting can be used to determine whether the expressed fusion protein has assembled into a complex with its expected binding partners, as determined from studies of the native cellular protein. Such analysis can be performed either with an antibody to the endogenous protein or with anti-GFP antibodies that function in immunoprecipitation assays. If a cell line is available or can be developed in which the protein of interest is deficient, rescue by the FPF can 
be examined. This approach was used in Chinese hamster ovary cells deficient in the ERCC1 DNA repair protein (Houtsmuller et al. 1999). Finally, if the specific function of the protein of interest is known, the ability of the fusion protein to replace the endogenous protein can be examined in an immunodepleted extract used for a functional assay, such as in vitro transcription or an in vitro pre-mRNA splicing reaction. In addition, in vivo functional assays can be performed to determine (1) whether the fusion protein is recruited to a site where a particular function is inducible, for example, transcription/pre-mRNA splicing (Misteli et al. 1997; Janicki et al. 2004) or DNA repair (Essers et al. 2002; Lisby et al. 2003), or (2) whether it is recruited to functional sites at a particular time in the cell cycle, for example, during DNA replication (Leonhardt et al. 2000).

Although FPs have been extremely useful, a major drawback to their utility as a protein tag is their large size $(27 \mathrm{kDa})$. Recently, a method has been developed that permits the fluorescent labeling of transient or stably expressed proteins containing a small tetracysteine sequence CCXXCC (where $X$ is any amino acid) (Griffin et al. 1998; Gaietta et al. 2002). Proteins carrying this motif can be labeled in vivo with the nonfluorescent, membrane-permeant biarsenical derivative of fluorescein, FIAsH-EDT2 (4', 5'-bis[1,3,2-dithioarsolan-2-yl]fluorescein-[1,2- ethanedithiol]2). FIAsH-EDT2 binds with high affinity (Kd $10 \mathrm{pM})$ to the tetracysteine motif, resulting in strong green fluorescence, whereas ReAsH-EDT2 (a biarsenical derivative of the fluorophore resorufin) emits a red fluorescence when bound to the tetracysteine tag (Gaietta et al. 2002). These two reagents have been used to label tetracysteine-motif-tagged intracellular proteins in living cells and also in combination to perform pulse-chase studies (Gaietta et al. 2002). The method is especially useful because not only is the ReAsH-EDT2 reagent fluorescent, but also, it can be used, by photoconverting diaminobenzidine to a highly insoluble reaction product, to visualize tagged proteins at high resolution by electron microscopy (Gaietta et al. 2002). For details on this method, see Biarsenical Labeling of Tetracysteine-Tagged Proteins for Tracking Existing and Newly Synthesized Pools of Proteins (Pattnaik and Panda 2009).

\section{REFERENCES}

Essers J, Houtsmuller AB, van Veelen L, Paulusma C, Nigg AL, Pastink A, Vermeulen W, Hoeijmakers JH, Kanaar R. 2002. Nuclear dynamics of RAD52 group homologous recombination proteins in response to DNA damage. EMBO / 21: 2030-2037.

Gaietta G, Deerinck TJ, Adams SR, Bouwer J, Tour O, Laird DW, Sosinsky GE, Tsien RY, Ellisman MH. 2002. Multicolor and electron microscopic imaging of connexin trafficking. Science 296: 503-507.

Griffin BA, Adams SR, Tsien RY. 1998. Specific covalent labeling of recombinant protein molecules inside live cells. Science 281: 269-272.

Houtsmuller AB, Rademakers S, Nigg AL, Hoogstraten D, Hoeijmakers $\mathrm{JH}$, Vermeulen W. 1999. Action of DNA repair endonuclease ERCC1/XPF in living cells. Science 284: 958-961.

Janicki SM, Tsukamoto T, Salghetti SE, Tansey WP, Sachidanandam R, Prasanth KV, Ried T, Shav-Tal Y, Bertrand E, Singer RH, et al. 2004. From silencing to gene expression: Real-time analysis in single cells. Cell 116: 683-698.

Leonhardt H, Rahn HP, Weinzierl P, Sporbert A, Cremer T, Zink D, Cardoso MC. 2000. Dynamics of DNA replication factories in living cells. J Cell Biol 149: 271-280.

Li S. 2006. Optimizing electrotransfection of mammalian cells in vitro. Cold Spring Harb Protoc doi: 10.1101/pdb.prot4449.

Lisby M, Mortensen UH, Rothstein R. 2003. Colocalization of multiple DNA double-strand breaks at a single Rad52 repair centre. Nat Cell Biol 5: 572-577.

Misteli T, Cáceres JF, Spector DL. 1997. The dynamics of a pre-mRNA splicing factor in living cells. Nature 387: 523-527.

Nagy A, Gertsenstein M, Vintersten K, Behringer R. 2006.
Electroporation. Cold Spring Harb Protoc doi: 10.1101/ pdb.prot4375.

Pattnaik AK, Panda D. 2009. Biarsenical labeling of tetracysteinetagged proteins for tracking existing and newly synthesized pools of proteins. Cold Spring Harb Protoc doi: 10.1101/pdb.prot5343.

Rizzo MA, Davidson MW, Piston DW. 2009. Fluorescent protein tracking and detection: Fluorescent protein structure and color variants. Cold Spring Harb Protoc doi: 10.1101/pdb.top63.

Sambrook J, Russell DW. 2006a. DNA transfection by electroporation. Cold Spring Harb Protoc doi: 10.1101/pdb.prot3751.

Sambrook J, Russell DW. 2006b. Transfection mediated by DEAEdextran: High-efficiency method. Cold Spring Harb Protoc doi: 10.1101/pdb.prot3876.

Sambrook J, Russell DW. 2006c. Calcium-phosphate-mediated transfection of eukaryotic cells with plasmid DNAs. Cold Spring Harb Protoc doi: 10.1101/pdb.prot3871.

Sambrook J, Russell DW. 2006d. Calcium-phosphate-mediated transfection of cells with high-molecular-weight genomic DNA. Cold Spring Harb Protoc doi: 10.1101/pdb.prot3872.

Smale ST. 2010a. Transfection by electroporation of RAW 264.7 macrophages. Cold Spring Harb Protoc doi: 10.1101/ pdb.prot5374.

Smale ST. 2010b. Calcium phosphate transfection of 3T3 fibroblasts. Cold Spring Harb Protoc doi: 10.1101/pdb.prot5372.

Smale ST. 2010c. DEAE-dextran transfection of lymphocyte cell lines. Cold Spring Harb Protoc doi: 10.1101/pdb.prot5373.

Spector DL, Goldman RD. 2010. Constructing and expressing fluorescent protein fusions. Cold Spring Harb Protoc doi: 10.1101/ pdb.top87. 


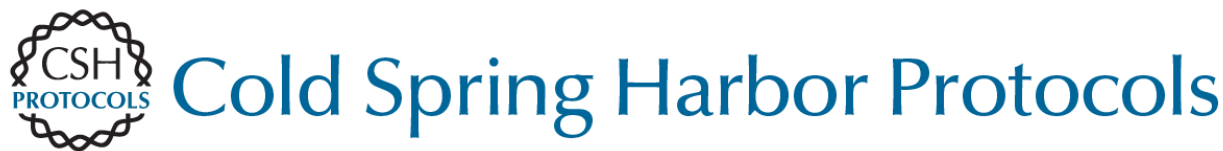

\section{Transfection of Mammalian Cells with Fluorescent Protein Fusions}

\author{
David L. Spector and Robert D. Goldman
}

Cold Spring Harb Protoc; doi: 10.1101/pdb.prot5517

\begin{tabular}{|c|c|}
\hline $\begin{array}{r}\text { Email Alerting } \\
\text { Service }\end{array}$ & Receive free email alerts when new articles cite this article - click here. \\
\hline $\begin{array}{l}\text { Subject } \\
\text { Categories }\end{array}$ & $\begin{array}{l}\text { Browse articles on similar topics from Cold Spring Harbor Protocols. } \\
\text { Analysis of Gene Expression (197 articles) } \\
\text { Analysis of Gene Expression in Cultured Cells (66 articles) } \\
\text { Analysis of Protein Expression in Cultured Cells (57 articles) } \\
\text { Cell Biology, general (1382 articles) } \\
\text { Cell Culture (301 articles) } \\
\text { Cell Imaging (525 articles) } \\
\text { DNA Delivery/Gene Transfer (344 articles) } \\
\text { DNA Delivery/Gene Transfer, general (341 articles) } \\
\text { Expression of Cloned Genes ( } 80 \text { articles) } \\
\text { Fluorescence (517 articles) } \\
\text { Fluorescent Proteins ( } 259 \text { articles) } \\
\text { Imaging/Microscopy, general (579 articles) } \\
\text { In Vivo Imaging (334 articles) } \\
\text { Labeling for Imaging (339 articles) } \\
\text { Live Cell Imaging (274 articles) } \\
\text { Molecular Biology, general (1293 articles) } \\
\text { Non-Viral Methods (226 articles) } \\
\text { Plasmids (154 articles) } \\
\text { Preparation of Macromolecules and Introduction into Cells (97 articles) } \\
\text { Use of Reporter Genes (124 articles) } \\
\text { Visualization (524 articles) } \\
\text { Visualization of Gene Expression (127 articles) } \\
\text { Visualization of Proteins (107 articles) }\end{array}$ \\
\hline
\end{tabular}

